\title{
Blood profile and Carcass Characteristics of West African Dwarf Goats Fed Groundnut Haulms and Cowpea Husk Supplemented with Brewers' Dried Grain
}

\author{
Babale DM*1, Millam JJ ${ }^{1}$ and Gworgwor $\mathrm{Z}^{2}$ \\ ${ }^{1}$ Department of Animal Production, Nigeria \\ ${ }^{2}$ Department of Animal Science and Range Management, Federal University of Technology, Yola, Adamawa State, Nigeria \\ *Corresponding author: Babale DM, Department of Animal Production, Adamawa State University, Mubi, Nigeria
}

ARTICLE INFO

Received: 慧 March 05, 2019

Published: March 15, 2019

Citation: Babale DM, Millam JJ, Gworgwor Z. Blood profile and Carcass Characteristics of West African Dwarf Goats Fed Groundnut Haulms and Cowpea Husk Supplemented with Brewers' Dried Grain. Biomed J Sci \& Tech Res 16(1)-2019. BJSTR. MS.ID.002789.

Keywords: Blood; Carcass; Goats; Groundnut Haulms; Cowpea Husk and Brewer's Dried Grain

\begin{abstract}
Blood profile and carcass characteristics of West African dwarf (WAD) goats fed groundnut haulms and cowpea husk supplemented with brewers' dried grain, were investigated. Twelve growing WADn goats of average age of 12 months, mean live weight of $12 \mathrm{~kg}$, were randomly allotted to four dietary treatments of $\mathrm{T}_{1}, \mathrm{~T}_{2}, \mathrm{~T}_{3}$ and $\mathrm{T} 4$ that had groundnut haulms at 10, 30, 70 and $90 \%$ combined with cowpea husks at 90, 70, 30 and $10 \%$ basal diet and supplemented with $150 \mathrm{~g}$ of brewers' dried grain (BDG). Randomized Complete Block Design (RCBD) was employed in the study. Parameters determined were growth, carcass characteristics and hematological indices. All data obtained were subjected to analysis of variance (ANOVA) using the SAS (2001) package. Means were separated using Duncan's multiple range test (Duncan, 1955). Effects of the experimental diets on blood profiles of the animals showed PCV values of 39.61 to $41.23 \%$, haemaglobin (Hb) 5.75 $6.55 \mathrm{~g} / \mathrm{dl}$, White blood cells, 9.20 to 11.00 , Red blood cell counts (RBC) $4.75-6.55 \mathrm{mg} / \mathrm{dl}$. Total proteins $\left(\mathrm{mg} \mathrm{dl}^{-1}\right)$, albumin $\left(\mathrm{mg} \mathrm{dl}^{-1}\right)$ and globulin $\left(\mathrm{mg} \mathrm{dl}^{-1}\right)$ of 3.95-4.51, 3.45-4.51 and 3.72-4.32 respectively were obtained in this study. Results of total proteins $\left(\mathrm{g} \mathrm{dl}^{-1}\right)$ showed no significant $(\mathrm{P}>0.01)$ differences between treatments $\mathrm{T}_{1}-\mathrm{T}_{3}$. In case of albumin (mg dl-1), there were significant $(\mathrm{P}>0.01)$ difference between treatment. Values for globulin (mg dl-1), also showed significant difference $(\mathrm{P}<0.01)$ among the treatment. For carcass parameters significant $(\mathrm{p}<0.05)$ differences were obtained across treatments with the exceptions of weights of flanks, rack and loins.
\end{abstract}

\section{Introduction}

Meat is one of the most important foods in the world and in some countries; it is considered an essential product with high consumption rate Ana et al. [1]. Differences in carcass, fat and conformation affect meat quality Panea et al. [2]. Carcass dimensions give information on its development, helping in determining the main assessment indices Eniolorunda et al. [3]. Carcass conformation is an important indicator of commercial value because carcass with better conformation has advantages of high lean content, proportion of high price cuts and greater muscle area (Kempten et al.). A carcass composition determines yield and meat sensorial characteristics. Therefore, carcass economic value is based on its conformation and composition Defa et al. [4]. It is reported Ibhaze et al. [5] that the nutritional and health status of animals cannot be compromised, hence the health status of the animal requires close scrutiny and proper examination of the blood. This fact is further strengthened by Babatunde et al. [6] that haematological parameters are important media used to monitor and evaluate the health and nutritional statuses of animals.

Therefore, the most readily available and fast means of assessing clinical and nutritionals effects of feeding trials is by the use of blood analysis Babatunde et al. [6]. Ibhaze [7] further stated that variation in blood parameters of animals are due to several factors such as feeding levels, age, sex, breed and physiological status of the animal. The differences have underlined the need to establish appropriate physiological baseline values for various breeds of livestock in Nigeria which could help in a realistic evaluation of 
the management practices, nutrition and diagnosis of their health conditions Opara et al. [8]. Determination of blood chemistry parameters such as glucose, total protein, blood urea nitrogen and cholesterol have been used in assessing nutritional status in cattle Gleen et al. [9]. Reduced feed or protein consumption in goats alters some blood chemistry profiles such as glucose, lipids and proteins Irkham et al. [10]. Aletor et al. [11] reported that the effects of diets on blood and serum chemistry should be of paramount interest since blood transports gases, nutrients and excretory products within the body. Information on blood profile and carcass characteristics of West African dwarf goats fed groundnut haulms and cowpea husk supplemented with brewers' dried grain is scanty. The research was therefore carried out to bridge this gap.

\section{Materials and Methods}

\section{Experimental Site}

The experiment was conducted at the Teaching and Research Farm of the Faculty of Agriculture, Adamawa State University, Mubi, Nigeria. Mubi is situated in the northern part of Adamawa State on Latitude 90011 north of the equator and Longitude $13^{\circ} 45^{1}$ east of the Greenwich Meridian at an altitude of $696 \mathrm{~m}$ above sea level. It has a land area of $4,728.77 \mathrm{~m}^{2}$ and population of 245,460 , Mubi region falls within the Sudan Savanna vegetation zone of the country (Saidu and Gadiga).

\section{Experimental Animals and Their Management}

Twelve West African Dwarf bucks of average age of 12 months and mean live weight of $12 \mathrm{~kg}$ were sourced from the local markets in and around Mubi. Their ages were determined through their dental formulae. They were then housed individually in pens measuring $1.5 \mathrm{~m}^{2}$ and $1.5 \mathrm{~m}$ high. The floor of the house was of concrete and covered with wood shavings to absorb moisture from the animals' dung and urine. The animals were quarantined for two weeks during which they were fed the experimental diets for adaptation and dewormed with Albendazol. At the end of the adaptation period, the animals were tagged, randomly allocated to treatments and balanced on weight basis for all the treatments. They were weighed to get the initial weights before embarking on data collection.

\section{Experimental Diets}

There were four treatments with each treatment replicated three times, making a total of twelve experimental animals. The treatments were $\mathrm{T}_{1}, \mathrm{~T}_{2}, \mathrm{~T}_{3}$ and $\mathrm{T}_{4}$ that received groundnut haulms at 10, 30, 70 and $90 \%$ combined with cowpea husks at 90, 70, 30 and $10 \%$ basal diet which was supplemented with $200 \mathrm{~g}$ of brewers' dried grain (BDG) across treatments. Randomized Complete Block Design (RCBD) was employed in the study Table 1.

Table 1: Experimental Diets.

\begin{tabular}{|c|c|c|c|c|}
\hline \multirow{2}{*}{ Ingredients } & \multicolumn{4}{|c|}{ Treatments } \\
\cline { 2 - 5 } & T1 & T2 & T3 & T4 \\
\hline GNHH (\%) & 10 & 30 & 70 & 90 \\
\hline CPHK (\%) & 90 & 70 & 30 & 10 \\
\hline
\end{tabular}

\begin{tabular}{|c|c|c|c|c|}
\hline BDG (g) & 200 & 200 & 200 & 200 \\
\hline
\end{tabular}

\section{Parameters Measured}

Parameters determined were proximate compositions of feed ingredients, daily dry matter intakes, and daily weight changes, digestibility of treatment diets, feed efficiencies, nutrients utilization and hematological indices. Proximate compositions were determined using the methods described by AOAC (2005). Metabolizeable were determined using bomb calorimeter. In determining the feed and nutrients utilization, the diets under investigation were given to the animals in known amounts. Each of the animals was restrained in steel metabolism cages designed to collect urine and feces separately. Urine was collected in $10 \mathrm{~N} \mathrm{H}_{2} \mathrm{SO}_{4}$ and the volume for each animal was measured and sampled daily for a period of fourteen days. Fecal outputs were also collected and weighed daily. The proximate compositions of faeces were determined using the methods described by AOAC (2005). Protein and Nitrogen levels in feed, faeces and urine were determined by standard Kjeldahl procedure (AOAC, 2005). Two samples were collected from each treatment. Hematological parameters were determined by drawing $10 \mathrm{mls}$ of blood from jugular veins of each animal into a sample bottle containing anticoagulant, Ethylene Diamine Tetra acetic Acid (EDTA).

These samples were used for the determination of the packed cell volume (PCV), Haemoglobin ( $\mathrm{Hb}$ ) concentration, Red blood cell counts (RBC) and White blood cell counts (WBC). The Total serum protein, Serum albumin, globulin and blood glucose were determined in the blood serum. The serum was obtained by allowing the blood to coagulate in order to separate the serum and cells. Packed cell volume was measured for each animal using the micro haematocrit method. Haemoglobin concentration was also measured using the Sahl's (acid haematin) method (Oni et al.). Red blood cells were determined with the aid of Neubaur counting chamber (Haemocytometer). Blood smears were used for total white blood cell (WBC) counts determination. Serum samples were also taken and used in the determination of serum urea, total cholesterol, total protein and albumin as described by Fasuyi et al. All data obtained were subjected to analysis of variance (ANOVA) using the SAS (2001) package. Means were separated using the Duncan's multiple range test (Duncan).

\section{Results and Discussion}

Effects of the experimental diets on blood profiles of the experimental animals are presented in Table 2. The PCV values which indicates the relative proportion of plasma and red blood cells of 39.61 to $41.23 \%$ obtained in this study were higher than 22 - $31 \%$ reported by Daramola et al. [12] for healthy female WAD goats and compared favorably with $36.9-40.12 \%$ obtained by Taiwo et al. [13]. The haemaglobin ( $\mathrm{Hb})$ of $5.75-6.55 \mathrm{~g} / \mathrm{dl}$ obtained in this study were not far from the $9.9 \mathrm{~g} / \mathrm{dl}$ reported by Opara et al. [8] for healthy female WAD goats, indicating the absence of microcytic hypochromic anaemia caused by iron deficiency and improper utilization for the formation of haemoglobin Olafadehan 
[14]. White blood cells of 9.20 to 11.00 ranges are an indicator of immune response to foreign bodies in the organism. The off shot in the white blood cells observed corroborates with the result of Waziri et al. [15] in Sahel goats.

Table 2: Blood Profiles of goats fed the experimental diets.

\begin{tabular}{|c|c|c|c|c|c|}
\hline \multirow{2}{*}{ Parameters } & \multicolumn{5}{|c|}{ Treatments } \\
\cline { 2 - 6 } & $\mathbf{T}_{\mathbf{1}}$ & $\mathbf{T}_{\mathbf{2}}$ & $\mathbf{T}_{\mathbf{3}}$ & $\mathbf{T}_{\mathbf{4}}$ & Sig. Level \\
\hline PCV (\%) & 40.50 & 41.23 & 39.61 & 41.22 & NS \\
\hline Hb (\%) & $7.33^{\mathrm{a}}$ & $5.75^{\mathrm{c}}$ & $6.05^{\mathrm{b}}$ & $6.30^{\mathrm{b}}$ & $* *$ \\
\hline RBC (10 $)$ & $6.55^{\mathrm{a}}$ & $4.75^{\mathrm{c}}$ & $5.45^{\mathrm{b}}$ & $5.72^{\mathrm{b}}$ & $* *$ \\
\hline WBC $\left(10^{\mathrm{g}}\right)$ & $10.50^{\mathrm{b}}$ & $9.20^{\mathrm{c}}$ & $10.20^{\mathrm{b}}$ & $11.0^{\mathrm{a}}$ & $* *$ \\
\hline Blood prot (mg/dl) & $4.51^{\mathrm{a}}$ & 4.35 & $4.45^{\mathrm{a}}$ & $3.95^{\mathrm{b}}$ & $* *$ \\
\hline Albumin (mg/dl) & $4.22^{\mathrm{a}}$ & $3.45^{\mathrm{b}}$ & $3.95^{\mathrm{b}}$ & $4.51^{\mathrm{a}}$ & $* *$ \\
\hline Globulin (mg/dl) & $4.32^{\mathrm{a}}$ & $3.72^{\mathrm{b}}$ & $3.94^{\mathrm{b}}$ & $4.23^{\mathrm{a}}$ & $* *$ \\
\hline Glucose (mg/dl) & $4.12^{\mathrm{a}}$ & $4.35^{\mathrm{a}}$ & $3.96^{\mathrm{b}}$ & $4.06^{\mathrm{a}}$ & NS \\
\hline Blood Nitrogen & $3.92^{\mathrm{b}}$ & $3.55^{\mathrm{b}}$ & $3.85^{\mathrm{b}}$ & $4.16 \mathrm{a}$ & $* *$ \\
\hline
\end{tabular}

The red blood cell counts (RBC) values obtained in this study (4.75 - 6.55mg/dl were lower than those of Okunlola et al. [16]. Values of total proteins $\left(\mathrm{mg} \mathrm{dl}^{-1}\right)$, albumin $\left(\mathrm{mg} \mathrm{dl}^{-1}\right)$ and globulin $\left(\mathrm{mg} \mathrm{dl}^{-1}\right)$ of 3.95-4.51, 3.45-4.51 and 3.72-4.32 respectively were obtained in this study. In addition, results of total proteins $\left(\mathrm{g} \mathrm{dl}^{-1}\right)$ showed no significant $(\mathrm{P}>0.01)$ differences between treatments $T_{1}$ $-\mathrm{T}_{3}$. In case of albumin $\left(\mathrm{mg} \mathrm{dl}^{-1}\right)$, there were significant $(\mathrm{P}>0.01)$ difference between treatment. Values for globulin $\left(\mathrm{mg} \mathrm{dl}^{-1}\right)$, also showed significant difference $(\mathrm{P}<0.01)$ among the treatment. For globulin values, that of $\mathrm{T}_{4}$ proved to be the highest. These suggested the importance of microbiologically increased level of supplementation in improving the nutritive value of small ruminant diets and performance. The values of the plasma total lipids (mg dl1), being glucose (3.96 - $\left.4.35 \mathrm{mg} \mathrm{dl}^{-1}\right)$ and blood-N (3.55 - $4.16 \mathrm{mg}$ $\mathrm{dl}^{-1}$ ) were obtained in this research. Results showed no significant differences among the treatments. Values for glucose were similar to $3.00-3.81 \mathrm{mg} / \mathrm{dl}$ obtained by Olafadehan [14].

Effects of the diets on carcass characteristics of goats are shown in Table 3. The weights of blood ranged from $0.93\left(\mathrm{~T}_{3}\right)$ to $1.14 \mathrm{Kg}\left(\mathrm{T}_{4}\right)$. The values were statistically significant $(\mathrm{p}<0.05)$ but did not follow any definite trend. The Hides/skin, non carcass, digestive organs, fore and hind limbs weights were significantly $(p<0.05)$ different across treatments. These values in this study were similar to those reported by Ukanwoko et al. [17], when they fed West African dwarf goats with cassava leaf- meal based diets. The similarities in this study may be due to the inclusion of the gut, head, legs and internal organs such as heart, kidney, lungs, spleen and liver in the dressed carcass. Cassey et al. [18] had reported that dressing percentage can be influenced by many factors such as fleece and hide weight alimentary trait size and fill, slaughtering procedure and portioning of body fat. Also the dressing method can affect the dressing percentage because parts which are considered as offal may not be considered offal in some dressing methods. For instance, Fasae et al. considers hot carcass weight to be carcass weight that includes head, gastro intestinal tract but minus legs [19]. However, Ukanwoko et al. reported warm carcass weight to exclude all internal organs, skin, head, feet as well as the visceral and abdominal fat. This coFmpared to the former will give a lower dressing percentage. Effects of the diets on whole sale cuts of growing West African dwarf goats showed that the weight for the breast, shoulder, legs and shanks were significantly $(p<0.05)$ different. However, the weights for flanks, racks, loins and total fat deposit showed no significant $(p>0.05)$ differences. Treatment $\mathrm{T}_{4}$ which received the highest level of groundnut haulms had the highest values for all the parameters.

Table 3: Effects of Diets on carcass characteristics of goats.

\begin{tabular}{|c|c|c|c|c|c|c|}
\hline \multirow{2}{*}{ Parameters } & \multicolumn{4}{|c|}{ TREATMENTS } & \multirow{2}{*}{ SEM } & \multirow{2}{*}{ Sig Lev } \\
\hline & $\mathrm{T}_{1}$ & $\mathrm{~T}_{2}$ & $\mathbf{T}_{3}$ & $\mathrm{~T}_{4}$ & & \\
\hline Live weight (Kg) & $12.75^{\mathrm{a}}$ & $12.95^{\mathrm{a}}$ & $11.75^{b}$ & $12.90^{\mathrm{a}}$ & 1.23 & * \\
\hline Blood weight (Kg) & $0.95^{\mathrm{b}}$ & $1.08^{\mathrm{a}}$ & $0.93^{\mathrm{b}}$ & $1.14^{\mathrm{a}}$ & 0.05 & $*$ \\
\hline Hides/skin (Kg) & $2.90 \mathrm{a}$ & $2.95 \mathrm{a}$ & $2.78_{b}$ & $2.78 \mathrm{~b}$ & 0.67 & $*$ \\
\hline Non carcass (Kg) & $2.77 \mathrm{~b}$ & $2.95_{b}$ & $3.20 \mathrm{a}$ & $3.22 \mathrm{a}$ & 0.72 & $*$ \\
\hline Digest. organs (Kg) & $3.23 a$ & $2.33 \mathrm{~b}$ & $3.15 a$ & $3.05 a$ & 0.69 & $*$ \\
\hline Fore/hind limbs (Kg) & $2.98 \mathrm{a}$ & $2.98 \mathrm{a}$ & $2.77 b$ & $2.94 \mathrm{a}$ & 0.43 & $*$ \\
\hline Breast (Kg) & $0.88 c$ & $0.85 c$ & $0.95 b$ & $1.10 \mathrm{a}$ & 0.03 & $*$ \\
\hline Shoulder (Kg) & $1.61 \mathrm{c}$ & $1.91 \mathrm{a}$ & $2.02 \mathrm{a}$ & $1.72 \mathrm{~b}$ & 0.04 & * \\
\hline Legs (Kg) & $1.11 \mathrm{~b}$ & $1.21 \mathrm{a}$ & $1.32 \mathrm{a}$ & $1.26 \mathrm{a}$ & 0.03 & $*$ \\
\hline Shanks (Kg) & $0.97 \mathrm{~b}$ & $0.98 \mathrm{~b}$ & $1.05 \mathrm{a}$ & $1.08 \mathrm{a}$ & 0.02 & $*$ \\
\hline Flanks (Kg) & 0.92 & 0.94 & 0.95 & 0.96 & 0.04 & NS \\
\hline Racks/Loins (Kg) & 1.30 & 1.32 & 1.32 & 1.28 & 0.05 & NS \\
\hline Fat (g) & 10.45 & 10.65 & 10.35 & 10.23 & 1.16 & NS \\
\hline
\end{tabular}




\section{References}

1. Ana G, Maribel VV, Mari MC, C Sanudo (2013) Acta Scientarum. Animal Sciences 35(4): 335-347

2. Panea B, Alberti P, Olleta JL, Campo MM, Ripoll G, et al. (2011) Intra breed variability and Relationship for carcass traits in cattle. Spanish Journal of Agricultural Science 6(4): 546-558.

3. Eniolorunda 00, Apata ES, AO Okubanio (2011) Body and carcass measurements of Rams fed graded Levels of Biscuit wastes-based diets. African Journal of feed Science 51: 333.

4. Defa R, A Teixeirra (2008) Sheep carcass quality. In Sheep meat carbo, pp. 373-400.

5. Ibhaze GA, Fajemisin AN (2017) Blood metabolites of intensively reared West African Dwarf goats fed pulverized Biofiber wastes based diets. Animal Research Journal 14(1): 2598-2603.

6. Babatunde GM, Fajimi AO, Oyejde AO (1992) Rubber seed oil versus palm oil in Broiler chicken diets. Effects on performance and nutrients digestibility, haematology and carcass characteristics. Animal feed sciences and technology 35: 133-146.

7. Ibhaze GA (2015) Feeding quality of fermented maize-cob based diets as feed for West African dwarf. Applied Tropical Agricultural Science 20(1): 52-56.

8. Opara MN, Udevi N, Okolic IC (2010) Haematological parameters and Blood chemistry of apparently healthy West African Dwarf goat in Owerri, South Eastern Nigeria. New York Science Journal 3(8): 68-72.

9. Gleen MJ, Wensing T (2006) Veterinary Q. 28(3): 90-104.

10. Irkham W, Sarmin K, PP Prabowo (2016) Influence of feed intake on blood chemistry parameters in goats. A.I.P conference proceedings 1755(1).

\section{ISSN: 2574-1241}

DOI: 10.26717/BJSTR.2019.16.002789

Babale DM. Biomed J Sci \& Tech Res

(C) This work is licensed under Creative

Commons Attribution 4.0 License

Submission Link: https://biomedres.us/submit-manuscript.php
11. Aletor IA, Agbele JO, RA Sobayo (2012) Effects of Diets on serum and Blood Chemistry of Goats.

12. Daramola JO, Adeloye AA, Fatoba TA, Soladoye AO (2005) Hematological and biochemical parameters of West African Dwarf goat. Livestock Research for Rural Development 17: 1-8.

13. Taiwo VO, Ogunsanmi AO (2003) Haematology, plasma, whole blood and erythrocyte biochemical values of clinically healthy captive reared grey duiker (Sylvicapra grimmia) and West African dwarf sheep and goats in Ibadan, Nigeria. Israel Journal of Veterinary Medicine 5: 43-47.

14. Olafadehan OA (2011) Changes in haematological diagnostic parameters of red Sokoto goats fed tannin-rich Pterocarpus erinaceus forage diets. Veterinarski Arhiv 81(4): 471-483.

15. Waziri MA, Abdullahi Y, Ribadu A, Sivachelvan N (2010) Changes in the serum proteins, haematological and some serum biochemical profiles in the gestation period in the Sahel goats. Verterinarski Arhiv 80(2): 215224.

16. Okunlola DO, Olorunnisomo OA, Binuomote RT, Amuda AJ, Agboola AS, et al. (2015) Heamatology and Serum Quality of Red Sokoto Goats Fed Baobab (Adansonia digitata L.) Fruit Meal Supplement. Journal of Natural Sciences Research 5(17): 54 -58.

17. AI, Ibeawuchi JA, Ukachukwu NW (2009) Growth performance and carcass characteristics of West African dwarf goats fed cassava peal mealbased diet. Proceeding at the $34^{\text {th }}$ annual conference of the Nigeria society for Animal production Uyo, pp. 476-479.

18. Cassey NH, Niekerk VWA (1999) the Boer goat, growth, nutrient requirements and meat quality. Performance test and origin. University of Pretoria, South Africa 1(4): 355-368.

19. Kempster AJ, Cuthbertson A, G Harington (1982) Relationship between conformation, the yield and Distribution of Lean meat in the Carcass of pigs, cattle and sheep. Meat Science 6(1): 37-53.

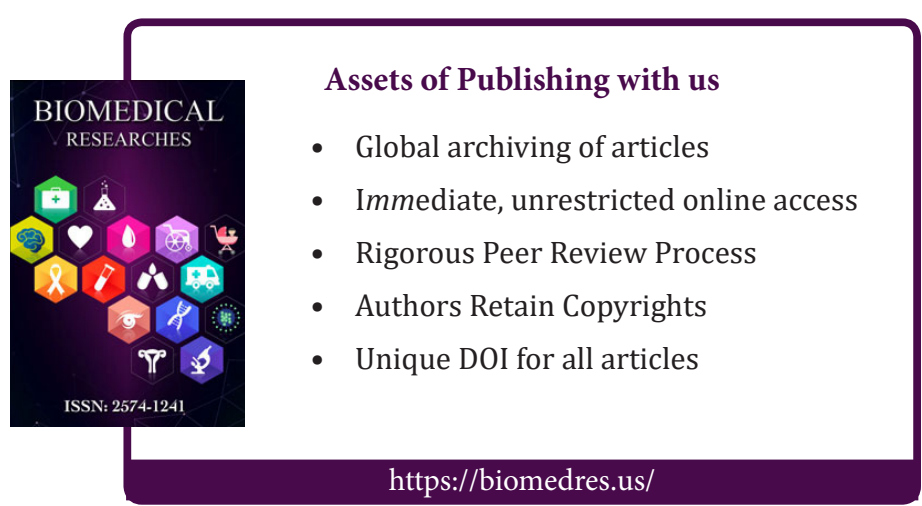

